\title{
Breeding Phenology and New Host List of the Black-Headed Duck (Heteronetta atricapilla) In Argentina
}

Author(s): María B. Cabrera, Diego Montalti, and Luciano N. Segura

Source: The Wilson Journal of Ornithology, 129(2):311-316.

Published By: The Wilson Ornithological Society

https://doi.org/10.1676/16-039.1

URL: http://www.bioone.org/doi/full/10.1676/16-039.1

BioOne (www.bioone.org) is a nonprofit, online aggregation of core research in the biological, ecological, and environmental sciences. BioOne provides a sustainable online platform for over 170 journals and books published by nonprofit societies, associations, museums, institutions, and presses.

Your use of this PDF, the BioOne Web site, and all posted and associated content indicates your acceptance of BioOne's Terms of Use, available at www.bioone.org/page/ terms_of_use.

Usage of BioOne content is strictly limited to personal, educational, and non-commercial use. Commercial inquiries or rights and permissions requests should be directed to the individual publisher as copyright holder. 


\title{
BREEDING PHENOLOGY AND NEW HOST LIST OF THE BLACK-HEADED DUCK (HETERONETTA ATRICAPILLA) IN ARGENTINA
}

\author{
MARÍA B. CABRERA, ${ }^{1}$ DIEGO MONTALTI, ${ }^{1}$ AND LUCIANO N. SEGURA ${ }^{1,2}$
}

\begin{abstract}
The Black-headed Duck (Heteronetta atricapilla) is a unique interspecific brood parasite among birds where the host species provides parental care for incubation only. Despite this unique system, there are few studies on this species biology and the list of hosts remains incomplete. We present information about breeding phenology of the Blackheaded Duck and an updated list of hosts obtained from a comprehensive review of egg collections deposited in the most important natural science museums of Argentina. We include five new hosts to the list: Great Grebe (Podiceps major), Maguari Stork (Ciconia maguari), White-cheeked Pintail (Anas bahamensis), South American Stilt (Himantopus mexicanus), and Long-winged Harrier (Circus buffoni). We found that solitary nesting host species were more likely to be parasitized earlier during the breeding season than colonial nesting species. The Black-headed Duck has an extended breeding season in central Argentina (Aug-Feb) as it is able to use a variety of hosts that breed in different times during the breeding season. With this contribution, the new list rises to 23 documented hosts of the Black-headed Duck belonging to eight different waterfowl orders. Received 17 March 2016. Accepted 1 July 2016.
\end{abstract}

Key words: breeding biology, egg collections, host list, interspecific brood parasitism, parasitic egg, waterfowl.

Avian brood parasites lay eggs in nests of other species (hosts) that incubate the parasite eggs and, in most cases, feed the parasite chicks (Davies 2000). Many interspecific avian brood parasite species are obligately parasitic and are completely dependent on a host to reproduce (Ortega 1998, Davies 2000). These females do not possess the ability to build nests, incubate eggs, or feed their nestlings (Sealy et al. 2002). Less than $1 \%$ of bird species are obligately parasitic, and this reproductive strategy has evolved independently at least seven times within birds (Rothstein 1990). Brood parasites generally reduce the reproductive success of their hosts (see Rothstein and Robinson 1998, Reboreda et al. 2003), generating a selection pressure that favors the evolution of antiparasitic defenses (Dawkins and Krebs 1979, Segura and Reboreda 2012).

The Black-headed Duck (Heteronetta atricapil$l a)$ is the only interspecific brood parasite species within the order Anseriformes (Madge and Burn 1988, Davies 2000). It is endemic to the Neotropical region, and its distribution mainly covers the central region of Chile and Argentina, Uruguay, southeastern Brazil, Paraguay and Bolivia (Carboneras 1992). Black-headed Ducks inhabit swamps, lakes, pools and marshes of permanent fresh waters with abundant emergent

\footnotetext{
${ }^{1}$ Sección Ornitología, División Zoología Vertebrados, Facultad de Ciencias Naturales y Museo, Universidad Nacional de La Plata. La Plata (B1900FWA), Buenos Aires, Argentina.

${ }^{2}$ Corresponding author; e-mail: luchosegura79@gmail.com
}

vegetation. Adult birds are usually paired from September to January (breeding season), and during winter, they gather in groups of up to 40 individuals (Madge and Burn 1988, Carboneras 1992, Cofré et al. 2007). There are few data on the breeding biology of Black-headed Ducks with most of the accounts relating to central-east Argentina (Rees and Hillgarth 1984; Carboneras 1992; Lyon and Eadie 2004, 2013).

The Black-headed Duck parasitizes a wide variety of species (Madge and Burn 1988, Lowther 2013) and presents a unique characteristic among brood parasites: the cost of parasitism for the host is restricted to the egg-laying and incubation stages, as the ducklings are able to care for themselves just a few hours after hatching (Weller 1968, Rees and Hillgarth 1984, Lyon and Eadie 1991, Davies 2000). To date, there is scarce information about the breeding biology of this species and in particular, on the list of hosts that this duck is able to parasitize.

In this study, we present information about some aspects of the breeding phenology of the Blackheaded Duck and its hosts, and present an updated version of the list of hosts obtained from a comprehensive review of egg collections deposited in the most important natural science museums of Argentina.

\section{METHODS}

We inspected the Museo Argentino de Ciencias Naturales Bernardino Rivadavia (MACN) and 
Museo de La Plata (MLP) egg collections extensively. These egg collections included information such as site, locality, province and country, date of egg collection, nest species, number of host and parasite eggs, state of incubation (early/late incubation) and collector. We also inspected other egg collections from Argentinian museums, but they did not have any data about hosts of Blackheaded Ducks. The most significant contribution belongs to Mr. Ronald Runnacles, an amateur ornithologist who conducted numerous studies in eastern Buenos Aires province $\left(36^{\circ} 22^{\prime} \mathrm{S}, 57^{\circ} 01^{\prime}\right.$ W) during 1932-1941. Mr. Runnacles collected numerous eggs with the aim of creating a private bird egg collection of the region. His collection was donated to MACN and MLP, along with all the original written records (manual forms and field notes). Field notes included additional information as weather conditions, nesting site characteristics, nest shape, nest material, adults (hosts or parasites) in the nest surroundings, and any evidence of recent incubation (adult flushing from the nest or warm eggs).

We also include data on parasitism by Blackheaded Ducks that occurred during a monitoring project on mixed breeding colonies of the Longwinged Harrier (Circus buffoni) and Cinereous Harrier (C. cinereus) in northeastern Patagonia $\left(40^{\circ} 06^{\prime} \mathrm{S}, 64^{\circ} 27^{\prime} \mathrm{W}\right)$ during the breeding season of 2012-2013.

Width and length of parasite eggs were measured to the nearest $0.05 \mathrm{~mm}$ using Vernier calipers. Egg volumes were calculated using Hoyt's (1979) equation: volume $=0.51 \times$ (length) $\mathrm{x}$ (width) ${ }^{2}$. We estimated the date parasitism occurred related to the date of our first parasitism event detected (day $1=2$ Aug), and we tested the relationship between egg measurements and date of the breeding season. We tested the relationship between the body mass of the host species (Dunning 2008) and parasite egg measurements. We also tested the relationship between the date of the breeding season and host nesting habits (i.e., solitary and colonial nesting species). For analysis purposes, we use the date of egg collection as an approximate date of parasitism, as all collected eggs were fresh. In addition to our data, we also used the parasitism date from Höhn (1975) and de la Peña (1987), since they were the only ones to report this data.
We consider as hosts the species in whose nest at least one egg of a Black-headed Duck was observed and/or collected whether the nest was active or abandoned. To compile the host list, we used also the available information published to date about the hosts of Black-headed Ducks (see Table 1). Reported values are means \pm S.E. Tests were two-tailed and differences were considered significant at $P<0.05$.

\section{RESULTS}

The egg collection at MACN contained 45 eggs from Black-headed Ducks, but only 24 of them had the host species data. The MLP contained 34 eggs, and 32 of them had the host species data. A complete host list of the Black-headed Ducks based in these collections is detailed in Table 1 .

During the breeding monitoring project of harriers on the southern coast of the Río Negro, northeastern Patagonia (see Methods), we observed a parasitism event in an abandoned Longwinged Harriers' nest. On 28 December 2012, a pair of Long-winged Harriers was observed building their nest on a flooded area with dense cattail (Typha latifolia). On 2 January 2013, there were two Long-winged Harrier eggs in the nest, and 4 days later the nest was abandoned with three Long-winged Harrier eggs and one egg from a Black-headed Duck.

Black-headed Ducks' eggs were $59.4 \pm 0.4 \mathrm{~mm}$ in length (range $=54.4-65.1 \mathrm{~mm} ; n=39$ eggs) and $44.3 \pm 0.3 \mathrm{~mm}$ in width (range $=40.7-48.9 \mathrm{~mm}$; $n=39$ eggs). Mean egg volume was $59.7 \pm 0.9$ $\mathrm{cm}^{3}$ (range $=49.9-71.9 \mathrm{~cm} 3 ; n=39$ eggs). Parasite egg dimensions did not vary within breeding season (Spearman's rank correlation: length, $\rho=-0.23, P=0.17$; width, $\rho=-0.14, P$ $=0.39$; volume, $\rho=-0.17, P=0.32 ; n=36$ eggs $)$, nor with hosts body mass (Spearman's rank correlation: length, $\rho=-0.07, P=0.67$; width, $\rho=0.08, P=0.62$; volume, $\rho=0.09, P=0.58 ; n=$ 39 eggs) or nesting habits (solitary vs. colonial nesting species; Mann-Whitney $U$-test: length, $z=$ $-0.18, P=0.85$; width, $z=1.44, P=0.15$; volume, $z=0.95, P=0.34 ; n=39$ eggs).

We found that parasitism in typically solitary nesting species (i.e., Great Grebe Podiceps major, Maguari Stork Ciconia maguari, Black-necked Swan Cygnus melanocoryphus, Coscoroba Swan 
TABLE 1. List of hosts of the interspecific brood parasitic Black-headed Duck. We provide each host Order, Family, Species, and the list of studies that have contributed with data. Question marks (?) indicate that authors only gave the genera, parenthesis () indicate the number of parasitized nests, and asterisks $\left(^{*}\right)$ indicate the new species reported in this study.

\begin{tabular}{|c|c|c|c|c|c|c|c|c|c|c|c|}
\hline & \multirow{2}{*}{$\begin{array}{c}\text { Daguerre } \\
1920 \\
\text { and } 1923\end{array}$} & \multirow[b]{2}{*}{$\begin{array}{c}\text { Wilson } \\
1923\end{array}$} & \multirow[b]{2}{*}{$\begin{array}{c}\text { Weller } \\
1968\end{array}$} & \multirow[b]{2}{*}{$\begin{array}{l}\text { Höhn } \\
1975\end{array}$} & \multirow[b]{2}{*}{$\begin{array}{c}\text { de La Peña } \\
1987\end{array}$} & \multirow{2}{*}{$\begin{array}{l}\text { Lyon } \\
\text { \& Eadie } \\
2013\end{array}$} & \multirow[b]{2}{*}{$\begin{array}{l}\text { Lowther } \\
2013\end{array}$} & \multicolumn{4}{|c|}{ This study } \\
\hline & & & & & & & & $\begin{array}{c}\text { Harriers } \\
\text { Project }\end{array}$ & $\begin{array}{l}\text { Runnacles } \\
\text { field notes }\end{array}$ & $\begin{array}{c}\text { MACN } \\
\text { collection }\end{array}$ & $\begin{array}{c}\text { MLP } \\
\text { collection }\end{array}$ \\
\hline $\begin{array}{l}\text { Podicipediformes } \\
\text { Podicipedidae }\end{array}$ & & & & & & & & & & & \\
\hline $\begin{array}{l}\text { Podiceps major }(1)^{*} \\
\text { Pelecaniformes } \\
\text { Ardeidae }\end{array}$ & & & & & & & & & $\mathrm{X}$ & & $\mathrm{X}$ \\
\hline $\begin{array}{l}\text { Nycticorax nycticorax } \\
\text { Threskiornithidae }\end{array}$ & & & & & & $\mathrm{X}$ & $\mathrm{X}$ & & $\mathrm{X}$ & $\mathrm{X}$ & $\mathrm{X}$ \\
\hline Phimosus infuscatus & & & & & $\mathrm{X}$ & & & & & $\mathrm{X}$ & \\
\hline Plegadis chihi & $\mathrm{X}$ & & $\mathrm{X}$ & & $\mathrm{X}$ & $\mathrm{X}$ & $\mathrm{X}$ & & $\mathrm{X}$ & & $\mathrm{X}$ \\
\hline $\begin{array}{l}\text { Platalea ajaia } \\
\text { Ciconiiformes } \\
\text { Ciconiidae }\end{array}$ & & & & & & & $\mathrm{X}$ & & $\mathrm{X}$ & & $\mathrm{X}$ \\
\hline $\begin{array}{l}\text { Ciconia maguari }(1) * \\
\text { Anseriformes } \\
\text { Anatidae }\end{array}$ & & & & & & & & & $X$ & & \\
\hline Dendrocygna bicolor & & & & $\mathrm{X}$ & & & $\mathrm{X}$ & & $\mathrm{X}$ & $\mathrm{X}$ & $\mathrm{X}$ \\
\hline $\begin{array}{l}\text { Anas bahamensis }(1) * \\
\text { Netta peposaca }\end{array}$ & & & $\mathrm{X}$ & & X & $X$ & $X$ & & $X$ & $\mathrm{X}$ & $\mathrm{X}$ \\
\hline Coscoroba coscoroba & $\mathrm{X}$ & & & & & $\mathrm{X}$ & $\mathrm{X}$ & & $\mathrm{X}$ & & $\mathrm{X}$ \\
\hline $\begin{array}{l}\text { Cygnus melanocoryphus } \\
\text { Anhimidae }\end{array}$ & & & & & & $\mathrm{X}$ & $\mathrm{X}$ & & $\mathrm{X}$ & $\mathrm{X}$ & $\mathrm{X}$ \\
\hline $\begin{array}{l}\text { Chauna torquata } \\
\text { Falconiformes } \\
\text { Falconidae }\end{array}$ & $\mathrm{X}$ & & & & & $\mathrm{X}$ & $\mathrm{X}$ & & $\mathrm{X}$ & & $\mathrm{X}$ \\
\hline $\begin{array}{l}\text { Milvago chimango } \\
\text { Accipitriformes } \\
\text { Accipitridae }\end{array}$ & $\mathrm{X}$ & $\mathrm{X}$ & & & & & $\mathrm{X}$ & & & & \\
\hline Rostrhamus sociabilis & & & & $\mathrm{X}$ & $\mathrm{X}$ & $\mathrm{X}$ & $\mathrm{X}$ & & & $\mathrm{X}$ & \\
\hline $\begin{array}{l}\text { Circus buffoni }(1)^{*} \\
\text { Gruiformes } \\
\text { Aramidae }\end{array}$ & & & & & & & & $\mathrm{X}$ & & & \\
\hline $\begin{array}{l}\text { Aramus guarauna } \\
\text { Rallidae }\end{array}$ & $\mathrm{X}$ & & & $\mathrm{X}$ & $\mathrm{X}$ & $\mathrm{X}$ & $X$ & & $X$ & & $\mathrm{X}$ \\
\hline Fulica leucoptera & $?$ & & & & $\mathrm{X}$ & & & & & & \\
\hline Fulica rufifrons & $?$ & & $\mathrm{X}$ & & $\mathrm{X}$ & $\mathrm{X}$ & $\mathrm{X}$ & & $\mathrm{X}$ & $\mathrm{X}$ & \\
\hline Fulica armillata & $?$ & & $\mathrm{X}$ & & & $\mathrm{X}$ & $\mathrm{X}$ & & $\mathrm{X}$ & $\mathrm{X}$ & $\mathrm{X}$ \\
\hline Pardirallus sanguinolentus & $\mathrm{X}$ & & & & & & & & $\mathrm{X}$ & & $\mathrm{X}$ \\
\hline $\begin{array}{l}\text { Pardirallus maculatus } \\
\text { Charadriiformes } \\
\text { Recurvirostridae }\end{array}$ & $\mathrm{X}$ & & & & & & $\mathrm{X}$ & & & & \\
\hline $\begin{array}{l}\text { Himantopus mexicanus }(1) * \\
\text { Laridae }\end{array}$ & & & & & & & & & $\mathrm{X}$ & & \\
\hline Chroicocephalus maculipennis & & ? & $X$ & & $\mathrm{X}$ & $\mathrm{X}$ & X & & X & $\mathrm{X}$ & \\
\hline
\end{tabular}

Coscoroba coscoroba, Southern Screamer Chauna torquata, Limpkin Aramus guarauna and Fulica spp.) occurred earlier in the breeding season than the typically colonial nesting ones (i.e., Blackcrowned Night-Heron Nycticorax nycticorax, Bare-faced Ibis Phimosus infuscatus, White-faced
Ibis Plegadis chihi, Roseate Spoonbill Platalea ajaja and Brown-hooded Gull Chroicocephalus maculipennis) (Mann-Whitney $U$-test: $z=2.13, P$ $=0.03$; Fig. 1). However, according to existing data within the same egg collection, there were no significant differences throughout the breeding 


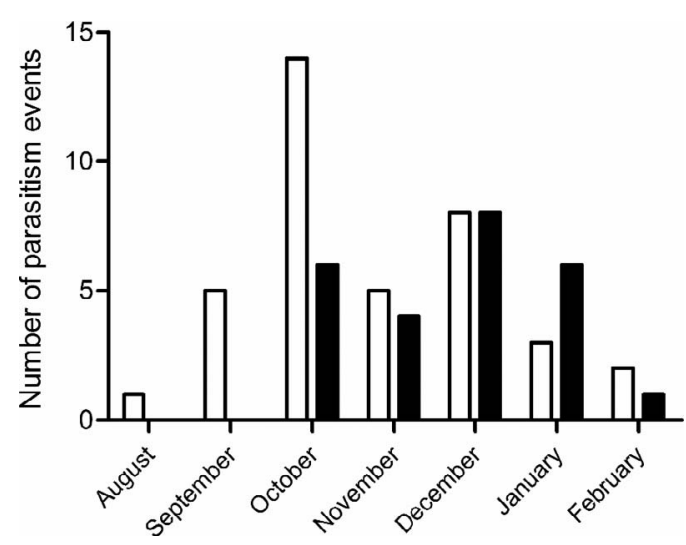

FIG. 1. Number of parasitism events of Black-headed Ducks at different times of the breeding season in centraleast Argentina. Bars show solitary (white bars) and colonial (black bars) nesting host species.

season between availability of theses solitary and colonial nesting species (Mann-Whitney $U$-test: $z$ $=1.86, P=0.24$; Fig. 2).

\section{DISCUSSION}

Reviewing the egg collections from MACN and MLP, we found four host species not included in the pre-existing lists: Great Grebe, Maguari Stork, White-cheeked Pintail (Anas bahamensis), and South American Stilt (Himantopus mexicanus) (Table 1). The egg collection data yielded 16 different hosts of Black-headed Ducks. Other documented lists of host species include those of Daguerre (1920, 1923): 8 hosts, Wilson (1923): 2 hosts, Weller (1968): 5 hosts, Höhn (1975): 3 hosts, de la Peña (1987): 8 hosts, Lyon and Eadie (2013): 11 hosts and the online version of Lowther (2013) with 15 hosts. The Maguari Stork had been listed as a host by Gibson (1920), but supposed parasitic eggs were later identified as Rosy-billed Pochards' eggs (see Weller 1968).

The observation of nest parasitism by Blackheaded Ducks in a nest of Long-winged Harriers is unexpected, as usually harriers are predators of some waterfowl, including the Black-headed Duck (Madge and Burn 1988, Bó et al. 1996). We suggest that the parasitic event could have occurred after the nest was abandoned.

In Europe, Rees and Hillgarth (1984) experimentally introduced six Neotropical potential hosts (Rosy-billed Pochard, Lake Duck Oxyura vittata,

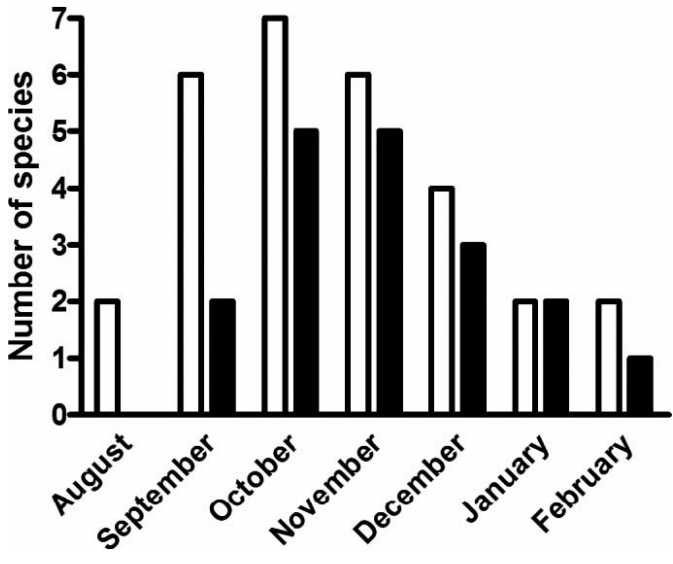

FIG. 2. Number of host species available for Blackheaded Ducks at different times of the breeding season in central-east Argentina. Bars show solitary (white bars) and colonial (black bars) nesting host species.

Silver Teal Anas versicolor, Red Shoveler A. platalea, Black-necked Swan and Common Moorhen Gallinula chloropus) and two exotic potential hosts (Wild Duck A. platyrhynchos and Gadwall $A$. strepera) in a large enclosure in order to observe the behavior of the Black-headed Duck. In this captivity context, authors only observed the use of the Rosy-billed Pochard as a host. Similarly, other studies in captivity conditions also reported the Rosy-billed Pochard, Red Shoveler, Common Moorhen, Cinnamon Teal (A. cyanoptera), and Silver Teal as hosts of the Black-headed Duck (Powell 1979, Todd 1979). These studies were not included in Table 1, because they were based in a captive environment and the host selection strategies may have been altered.

Solitary nesting host species were more parasitized early during the breeding season (Aug, Sept, and Oct), while colonial nesting ones were more parasitized between the middle and the end of the breeding season (mainly Nov to Feb). This strategy cannot be explained by simple differences in host availability, since we did not find any difference in that regard for solitary and colonial hosts throughout the season. On the one hand, it is quite accepted among researchers that waterfowl that nest early in the breeding season tend to have greater success in relation to those that nest late (Blums et al. 2002). On the other hand, colonial nesting waterfowl have lower predation costs than solitary ones (Picman et al. 2002). Would it be 
possible that Black-headed Ducks are taking advantage of both scenarios for maximizing their own breeding success? We cannot speculate accurately on the functionality of this strategy, because there are not enough available data on the effect of breeding season date on host and parasites' reproductive success for these Neotropical waterfowl. What is clear is that Black-headed Ducks have a very extensive breeding season (Aug-Feb) to take advantage of a variety of host nesting times.

With this contribution, we are adding valuable information on the breeding phenology of Blackheaded Ducks and reporting five new host species (three unreported families of waterfowl), completing a list of 23 hosts of eight different waterfowl orders. Apparently, the Black-headed Duck is not a specialized brood parasite (but see Weller [1968] and Lyon and Eadie [2004] that suggested there is a marked preference for two effective hosts: the Red-gartered Coot and the Red-fronted Coot). It is very likely that the host list is considerably wider, since there have not been many systematic and comprehensive studies in waterfowl breeding biology, resulting in a potential underestimation of the host list. Further studies on this particular brood parasite are necessary to clarify the real number of its suitable hosts and to highlight the host selection strategies used by Black-headed Ducks.

\section{ACKNOWLEDGMENTS}

We are grateful to curators of ornithological collections: Paulo E. Llambías (Museo de Ciencias Naturales y Antropológicas Juan Cornelio Moyano, Mendoza), Sara Bertelli (Museo de Ciencias Naturales Miguel Lillo, Tucumán), Pablo Tubaro (Museo Argentino de Ciencias Naturales, Ciudad Autónoma de Buenos Aires), and Carlos Darrieu (Museo de La Plata). We also thank Adrian Jauregui and two anonymous reviewers for helpful comments to a previous version of this manuscript. DM and LNS are CONICET Research Fellows.

\section{LITERATURE CITED}

Blums, P., R. G. Clark, and A. Mednis. 2002. Patterns of reproductive effort and success in birds: path analyses of long-term data from European ducks. Journal of Animal Ecology 71:280-295.

Bó, M. S., S. M. Cicchino, And M. M. Martínez. 1996. Diet of Long-winged Harrier (Circus buffoni) in southeastern Buenos Aires Province, Argentina. Journal of Raptor Research 30:237-239.
Carboneras, C. 1992. Family Anatidae (ducks, geese and swans). Pages 536-630 in Handbook of the birds of the world. Volume 1. Ostrich to ducks (J. del Hoyo, A. Elliott, and J. Sargatal, Editors). Lynx Edicions, Barcelona, Spain.

Cofré, H. L., Y. A. Vilina, J. Aguirre, W. Egli, M.-D. García, H. Kocksch, J. Rottmann, H. Seeger, and C. TALA. 2007. Local distribution, abundance and conservation of Black-headed Duck in the Mediterranean wetlands of Chile. Waterbirds 30:412-416.

Daguerre, J. B. 1920. Observaciones sobre los patos Metopiana peposaca y Heteronetta atricapilla. Hornero 2:61-62.

Daguerre, J. B. 1923. Parasitismo del pato, Heteronetta atricapilla. Hornero 3:194-195.

Davies, N. B. 2000. Cuckoos, cowbirds and other cheats. T. and A. D. Poyser Ltd., London, United Kingdom.

Dawkins, R. And J. R. KRebs. 1979. Arms races between and within species. Proceedings of the Royal Society of London, Series B 205:489-511.

DE LA PeÑA, M. R. 1987. Nidos y huevos de aves argentinas. Imprenta LUX, Santa Fe, Argentina.

DunNing JR., J. B. (Editor). 2008. CRC handbook of avian body masses. Second Edition. CRC Press, Boca Raton, Florida, USA.

GiBson, E. 1920. Further ornithological notes from the neighbourhood of Cape San Antonio, province of Buenos Ayres. Part III. Phœnicopteridæ-Rheidæ. Ibis 2:1-97.

HöHN, E. O. 1975. Notes on Black-headed Ducks, Painted Snipe, and Spotted Tinamous. Auk 92:566-575.

Hoyt, D. F. 1979. Practical methods of estimating volume and fresh weight of bird eggs. Auk 96:73-77.

Lowther, P. E. 2013. Host list of avian brood parasites. 1: Anatidae. Field Museum, Chicago, Illinois, USA. www.fieldmuseum.org/sites/default/files/plowther/ 2014/09/24/heteronetta-29apr2013.pdf (accessed 19 Feb 2016).

Lyon, B. E. AND J. M. EAdIE. 1991. Mode of development and interspecific avian brood parasitism. Behavioral Ecology 2:309-318.

Lyon, B. E. AND J. M. EAdIE. 2004. An obligate brood parasite trapped in the intraspecific arms race of its hosts. Nature 432:390-393.

Lyon, B. E. AND J. M. EAdIE. 2013. Patterns of host use by a precocial obligate brood parasite, the Black-headed Duck: ecological and evolutionary considerations. Chinese Birds 4:71-85.

Madge, S. AND H. BuRn. 1988. Waterfowl: an identification guide to the ducks, geese and swans of the world. Houghton Mifflin Co., Boston, Massachusetts, USA.

Ortega, C. P. 1998. Cowbirds and other brood parasites. University of Arizona Press, Tucson, USA.

Picman, J., S. Pribil, ANd A. Isabelle. 2002. Antipredation value of colonial nesting in Yellow-headed Blackbirds. Auk 119:461-472.

Powell, A. 1979. Cuckoo in the nest. Wildfowl News $81: 15-16$.

Reboreda, J. C., M. E. Mermoz, V. Massoni, A. A. Astié, AND F. L. RABUfFETTI. 2003. Impact of brood parasitism 
by Shiny Cowbirds (Molothrus bonariensis) on the reproductive success of their hosts. Hornero 18:77-88.

Rees, E. C. and N. Hillgarth. 1984. The breeding biology of captive Black-headed Ducks and the behavior of their young. Condor 86:242-250.

Rothstein, S. I. 1990. A model system for coevolution: avian brood parasitism. Annual Review of Ecology and Systematics 21:481-508.

Rothstein, S. I. And S. K. Robinson. 1998. The evolution and ecology of avian brood parasitism: an overview. Pages 3-56 in Parasitic birds and their hosts: studies in coevolution (S. I. Rothstein and S. K. Robinson, Editors). Oxford University Press Inc., New York, USA.
Sealy, S. G., D. G. McMaster, and B. D. Peer. 2002. Tactics of obligate brood parasites to secure suitable incubators. Pages 254-269 in Avian incubation: behaviour, environment, and evolution (D. C. Deeming, Editor). Oxford University Press, Oxford, United Kingdom.

Segura, L. N. and J. C. Reboreda. 2012. Red-crested Cardinal defences against Shiny Cowbird parasitism. Behaviour 149:325-343.

ToDD, F. S. 1979. Waterfowl: ducks, geese and swans of the world. Sea World Press, San Diego, California, USA.

Weller, M. W. 1968. The breeding biology of the parasitic Black-headed Duck. Living Bird 7:169-208.

WiLson, A. S. 1923. Huevos de pato en un nido de Chimango. Hornero 3:192. 